\title{
CONSUMER DEMAND: ONLINE OR RETAIL STORES
}

\author{
Aurelija Burinskiene ${ }^{1}$, Diana Daskevic ${ }^{2}$ \\ ${ }^{1}$ Vilnius Gediminas Technical University, Lithuania \\ ${ }^{2}$ Mykolas Romeris University, Lithuania \\ crossref http://dx.doi.org/10.5755/j01.em.19.2.4742
}

\begin{abstract}
Consumers' interest in online trade increases constantly. Therefore, this paper addresses issues of such kind. The study presented contains the following aspects. First, consumer choice models are analysed in the paper. Second, the factors, which describe consumer choice between the online and retail stores, are determined through literature analysis; benefits and limitations for each store are reviewed herein. Third, the decision making tool, which incorporates above mentioned factors, is presented. Multiple criteria evaluation methods used for consumer choice analysis are overviewed, as well. The article is based on comparative and multiple criteria analysis. Multiple criteria evaluation method (COPRAS) is used for the development of a decision making tool.
\end{abstract}

The aim of the research is to propose decision making tool used to make a choice between online and retail store. The proposed tool can be useful for researchers who analyse consumer's behaviour.

The type of the article: Theoretical article.

Keywords: online store, retail store, consumer, retail mix.

JEL Classification: L81, D9, D61.

\section{Introduction}

The analysis of scientific literature on e-commerce, which is published by leading world publishers (Oxford University Press, Cambridge University Press, Harvard University Press, Springer, M. E. Sharpe, Routledge, etc.), shows that 67.1 thousand publications focus on retail trade. Most of these authors investigate consumers' behaviour and only $1.6 \%$ of authors incorporate online stores analysis into their studies. The situation is similar with online trade topics in the literature. There are only $0.73 \%$ of scientific publications dedicated to both online and retail trade. This means that research, in which the integrated approach is analysed, can be regarded as relevant.

In applied theories of behavioural economics and other sciences there is a lack of scientific generalisations and solutions on the topic of the consumer choice among online and retail stores; especially there is a lack of theoretical solutions, which are adequate to nowadays challenges. There are a lot of behavioural studies: starting with basic behavioural research, the applied behaviour analysis, largely focusing on social marketing applications; and continuing with classical studies of consumer attitudes and behaviours. Nevertheless, there are advanced studies dedicated to retail, which show that consumers interested in purchasing at stores if appropriate retail mix satisfies them. Knowing that the mix of retail variables is dominant in studies dedicated to retail, this study aims to suggest the decision making tool used to make choice between online and retail store. For the comparison of stores, authors propose to use multiple criteria evaluation method COPRAS. Such is the first time, when the attributes of the retail mix are used for stores' ranking and incorporated into multiple criteria decision making tool. Previous studies researched the impact of the marketing mix on customer satisfaction using a multiple criteria decision making outranking methodology or the effect of the retail mix on consumer buying interest using the multiple linear regression analysis.

Consumers' interest in online trade increases constantly. Online stores are opening up to fundamentally new possibilities: a consumer can visit the website of trade centre and choose an item from a wide range of stock. Moreover, consumers can easily find, choose and even make a 
'purchase-sale' deal with a direct producer online. This encourages more and more consumers to buy products directly. However, across different stores, the online store is the fastest developing. Its sales growth rates, each year, are more than $11 \%$ higher compared to other stores (TV stores, retail stores, representatives visiting client, etc.), whose sales growth rates each year are lower than 3\% (Burinskienė \& Burinskas, 2012).

Thus, the results of such analysis show the importance of the research, which combines the analysis of online and retail stores from the consumer perspective. The paper presents the results of investigations in this context.

The study presented in the paper contains three different aspects. First, consumer choice models are analysed. Second, the attributes, which describe consumer choice between online and retail store, are determined through literature analysis; benefits and limitations for each store are reviewed herein. Third, the decision making tool, which incorporates above mentioned attributes, is presented. The study results regarding the methods used for consumer choice analysis are overviewed, as well. The methods of research: comparative and systematic analysis.

The scientific novelty of the study - composed decision making tool, which incorporates attributes used for consumer choice between online and retail stores.

\section{Consumer's choice models}

Consumer's behaviour involves different types of decisions. First, consumers decide which products to purchase from all available in the market. Second, they decide what quantity to purchase of items they have selected. In general, these two decisions are explained by scientists using the customer behaviour model. There are different versions of the model. One version of customer behaviour model attempts to depict rational brand choice behaviour by the buyers under conditions of incomplete information and limited ability. Another version of the model offers no detailed explanation of the internal factors, which may affect the personality of the consumer, and how the consumer develops his attitude toward the product. For example, scientists examine situational factors that may increase consumption or reinforce feelings of satisfaction for brands already being used. But in general, this model (Gluhovsky, 2009) is capable of including too many variables. In our study, we have to involve store choice attribute.

Consumer behaviour theory is concerned with the complex interaction of cultural, psychological, economic, and social factors involved in the process of consumers' decisions. The Behavioural Perspective Model (described by Foxall (2009)) - decision making tool that embodies benefits and costs associated with consumer choice and can be used to interpret the wide range of consumer behaviour cases like every day purchasing, innovative consumer choice, imitation, 'green' consumer behaviour, and compulsive behaviours in shopping. The different types of behaviour include maintenance (activities necessary for the consumers physical survival and welfare: food and the societal obligations), accumulations (behaviours involved in certain kinds of saving, collecting, and instalment buying), pleasure (consumption of popular entertainment), and accomplishment (behaviour showing social and economic achievement, and personal attainment). These four types of behaviour can be applied to the communications of innovations of new products. The last presented accomplishment category will be the first group exposed to the product, for the consumers-initiators. As the life of the product continues, the other three behaviours will come into effect in order of early imitators (pleasure), later imitators (accumulation), and last adopters (maintenance) (DiClemente \& Hantula, 2003).

Foxall (2009) thinks that the basic model can be used to interpret consumer behaviour (not in isolation from the marketing influences that shape it). The model explains consumer behaviour with reference to physical surroundings, rules, and temporal frame. The consumer's 'learning history' includes accumulated past knowledge, information, and direct and indirect experience (Alshurideh, 2014). Foxall (2009) claimed that the model covers a distinct gap in the literature. Applied behaviour analysis is lacking an integrative model of consumer behaviour based on a critical evaluation of behaviour theory. The model has been used to investigate different marketing phenomena, consumer brand choice (Alshurideh, 2014). 
Hauser and Urban (2011) proposed a normative methodology for modelling consumer response to innovation. This methodology integrates knowledge in the fields of psychometrics, utility theory, and stochastic choice modelling. The methodology consists of consumer response process. Consumer response is based on individual choice process and the aggregation of predictions of individual choices.

Other authors have described the 'behaviouristic' advertisements. Authors are arguing that one key responsibility of the consumer behaviourists is to teach people how to be better consumers and information seekers, and not necessarily how to consume more. In further conceptual analysis, specific examples of applications of a behaviour modification perspective in marketing, principles of classical conditioning, and orientation to ecology were delivered (DiClemente \& Hantula, 2003).

The most popular consumer choice models used in marketing are multinomial logit models (Zeileis \& Croissant, 2010). They involve individual and/or alternative specific variables and demonstrate the statistical significance of brand loyalty, space loyalty, store promotions, price, and other marketing mix variables used to measure sales and market share. Authors compared multinomial logit models to regression models and clarified that multiple attribute choice modelling is included only in multinomial logit models. Especially multinomial logit models (which are revising two or more consumer's decisions) have been introduced. The integration is foreseen through the utility function or the set of decision options (Louiviere, Hensher \& Swait, 2000).

The model suits for the estimation of psychological trade-off also it is capable of interacting between attributes. Still, it doesn't take into account the number of items per purchase, so, it can give a poor reading of market share.

Another approach starts with household utility function and covers dynamic phenomena, which often allows consumer to become 'looking forward'. This means that a future account is included into present decision. Bucklin and Lattin (1991) model is used to capture store switching effects. The store choice model uses multinomial logit expression. Key variables are as follows: probability that the store will be selected on a shopping trip, loyalty to chain variable, and categorywide feature variable (weighted average across brands). One difficulty arises seeking to measure the effect of promotions for store choice: consumer makes store choice decision not only based on location factors, waiting lines but also based on individual category's price and promotions. Standard logit model for store choice assumes that the consumer knows all promotions and prices per store, which seems impossible. It seems more likely that there is indirect store switching: different stores are selected for promotional purchase and regular purchase. Over time consumers, become more price and promotion sensitive. This is known as producers initiated forward buying process.

Buying is different in e-environment; consumers may choose from a greater number of online stores and commodities. Different set of variables can be examined. Individual and family, man and woman decision making is different. Household collective decision is synergistic with individual and relational identities of family members; finally family has a shared vision about different options that would serve family identity needs (Epp \& Price, 2008). Zhang and Krishnamurthi (2004) provide a decision-support system for planning promotions in online stores. Herein, it is presented that positive purchase feedback results to more repeat purchases.

The site usage models focus on the time-related dimensions of web site usage. They involve different patterns of behaviour on the site: some are related to the usage of web site (visits of offline retailers, shoppers information searching, future purchasing horizons), others - to shopping (they are oriented to consumers ready to buy). Ansari and Mela (2003) proposed simultaneous individual level model, which consists of order size, order incidence, and channel choice. In the model, these three decisions are influenced by the four sets of such effects: consumer demographics (age, income, number of consumers who migrated to web), previous experience with purchasing channel, marketing activity (mails, leaflets received by consumer), and time (seasonality, fashion trends, etc.). Results from channel choice model show that companies may influence channel choice through marketing effort. The authors mention that this could be due to lower switching costs to web and decreasing costs associated with offline trade (Wierenga, 2008). To facilitate assessment of the impact of online activities on offline sales, Biyalogorsky and Naik (2003) developed a method 
that allows retailers to use readily available market data for making informed decisions. The proposed model determines (1) the extent to which online sales cannibalize offline sales and (2) whether online activities build online equity for the firm.

In the modelling set-up developed by Biyalogorsky and Naik (2003), the companies sell through retail stores and new online stores. The objective of the model is to determine how online activity cannibalizes offline sales. It has become apparent that consumers are at least as loyal to online stores as to retail stores. It is also clear that more products are available in online stores than consumers can found in offline stores. Thomas and Sullivan (2005) find that consumers, who purchase across in all channels, are not different from those, who purchase in single channel. But if shopping in multiple channels increases consumer profits he tends to purchase items in multiple channels (Wierenga, 2008).

Finally, this presented model can be extended in several interesting directions. The model starts with measures of consumer online behaviour. Such behaviour, obviously, is the result of marketing actions taken by the firm both online and offline. Given appropriate measures of the firm's marketing efforts, the model can be extended backwards to assess how the marketing efforts led to online behaviour, providing a fuller characterization of how marketing activities impact online and offline sales. Another extension is to consider time-varying parameters. Given the changing nature of the Internet, the amount of cannibalization may increase as the Internet matures. With longer time series that provide more degrees of freedom, one might address this issue by specifying an econometric model for change over time (Biyalogorsky \& Naik, 2003). Still more work is needed to understand the effect of competition between sites. New decision making tool might be developed to capture the nature of online retail competition (e.g. how can 'distance' or location be modelled when competition occurs online versus offline?) (Wierenga, 2008).

In another model of consumer behaviour, the Behavioural Ecology of Consumption behaviours comprises search, choice, consumption, and disposition of goods, and they are seen as selected through evolutionary processes (DiClemente \& Hantula, 2003).

The theoretical analysis of consumers' choice models shows that for the purpose of modelling consumer choice between online and retail stores, the new decision making tool has to be formulated, as existing models do not involve theoretical knowledge of the retail mix for both online and retail stores. Bellow criteria associated with retail are overviewed.

\section{Criteria used to model consumer's choice}

Online retailers organise their services to cover logistics, distribution, and online payments. From an online retailer's perspective, digital technologies and the Internet create an opportunity to cross barriers by time and geography. A multiple linear regression analysis concluded that the retail mix affects the consumer buying interest in the Department Store, either simultaneously or partially. Store design and retail display is a variable of the retail mix, which has the dominant influence on consumer buying interest in the Department Store. Knowing that the mix of retail variables is dominant in studies dedicated to retail, this chapter is used to specify retail mix attributes: customer service, location, pricing, store design and display, merchandise assortments, and communication.

First retail mix attribute - customer service (Wolfinbarger \& Gilly, 2001). As consumers can stop on the Internet in the comfort of their home environment and get delivery service. It saves time and effort, and they are able to shop any time of the day or night. Especially for consumers that, owning to tier extended working hours, only have the small amount of free time, online shopping is an excellent opportunity. Some retailers have reacted to this by focusing on retail formats that get consumers in and out of stores quick and provide a high degree of reliability that shoppers would find what they need. Retailers are taking pains to convince shoppers to stay longer and take their time to enjoy the shopping experience.

Second retail mix attribute - location (Avery, 1996). Consumers who are not able to shop in traditional stores owing to illness or other immobilizing factors have the ability to shop on the Internet by fulfilling their shopping goals. For consumers who have to travel large distances to stores that provide them with the articles they need, shopping on the Internet is a viable alternative to 
overcome this 'geographical distance'. Meier-Pesti and Trubenbach (2009) study showed necessity to ascertain the magnitude of online time savings, which are required to overcome 'geographical distance'. On the other hand, e-commerce has the potential to enable the purchaser to obtain commodities, which are not available in consumer's own country (Commission of the European Communities, 2009). It is evident that, based on Eurobarometer (2008) survey, on average $9 \%$ of the European Union citizens take purchasing trips to another member state. For those and other customers this is the most important possibility to purchase online and receive personal wealth.

Third retail mix attribute - pricing. The main aspects, why consumers are satisfied with the online shopping, are the possibility to compare prices. In practice, the price of the commodity presented at traditional stores at the consumer's country usually includes intermediate's mark-up. It is calculated that on average wholesale mark-up is equal to $17 \%$ and retail mark-up - to $33 \%$ (Statistics department of Lithuania, 2009). This means that online stores (especially) of manufacturers can offer different prices, which gives price savings for the consumer. The prices of commodities, which are sold in traditional stores and online stores, are different due to intense competition in both: physical and virtual environments (Snieška, Virvilaitè, Kvainauskaitė, Neverauskas, Gatautis \& Dovalienè, 2007). Actually, the final price (when taxes and delivery costs are included) for the item at supermarket and online is different.

Prices in both online and traditional stores show that it is necessary to ascertain the magnitude of online price savings. In the report 'The Mystery Shopping evolution of cross-border e-commerce in the EU' is stated that the final price from online shop usually is $10 \%$ lower than the price for the same item reported in traditional stores. Compared to retail stores, online stores may provide consumers cheaper alternatives, depending on the sector and commodities. According to the study one third of EU citizens are willing to consider the purchasing of commodities from another state over Internet, because they are cheaper (Meier-Pesti \& Trubenbach, 2009).

Fourth retail mix attribute - store design and display. Online shopping incorporates many of the same characteristics as 'real world shopping' (Chen \& Leteney, 2000), consumers are in a different frame comparing to the traditional way (Burke, 2002). Therefore, it is important to identify the analogies and differences between traditional shopping specifics and the features of online shopping. Retailers have to be aware of the advantages and disadvantages of online shopping compared to the traditional one seeking to understand consumers' motives to choose the channel over the other. Lohse, Bellman and Johnson (2000) set up a table to provide an overview on how the features of a brick-and-mortar store relate to online store. In the table, we have translated these store-features to features relating to online and retail store.

The data bellow (see Table 1) shows that all traditional retail stores features are also present for online shopping, but in most cases in different form and not always a level satisfactory to consumers. For examples, online shoppers are not able to gain experience: feeling the atmosphere and touching or trying merchandise (Lee, Kuo \& Russell, 1999).

Table 1. Features relating to online and retail store

\begin{tabular}{|l|l|}
\hline \multicolumn{1}{|c|}{ Retail stores } & \multicolumn{1}{c|}{ Online stores } \\
\hline Salesclerk service & $\begin{array}{l}\text { Product descriptions, information, pages, gift services, search function, } \\
\text { and clerk on the phone/e-mail. }\end{array}$ \\
\hline Sales promotion & $\begin{array}{l}\text { Online games and lotteries, links to others sites of interest, appetizer } \\
\text { information, and special offers }\end{array}$ \\
\hline Store windows display & Home page \\
\hline Store atmosphere & Interface consistency, store organization, interface, and graphic quality \\
\hline Aisle products & Featured products on hierarchical levels of the store \\
\hline Store layout & Screen depth, browse and search functions, indicates, and image maps \\
\hline Number of floors in the store & Hierarchical levels of the store \\
\hline $\begin{array}{l}\text { Number of store entrances and store } \\
\text { outlets/branches }\end{array}$ & Numbers of links to a particular online retail store \\
\hline $\begin{array}{l}\text { Checkout cashier } \\
\text { Ondine shopping basket and/or order from limited to image quality and } \\
\text { description, potential for sound, and video applications }\end{array}$ \\
\hline
\end{tabular}

Source: Lohse, Bellman and Johnson (2000) 
Fifth retail mix attribute - merchandise assortments. In case consumers need acquire tailors products, like especially sizes clothing or larger shoes, which are not available in the retail store, shopping on the Internet is an option for them to purchase. The range of goods in a hypermarket is limited to 40-60 thousand items, whereas there are no limitations on having a wider range of goods in the online store.

Sixth retail mix attribute - communication. There are two streams of communication: external communication and internal communication, which has two directions: frontward (from the retailer to customer) and backward (from client back to the retailer). Comparing online store with other purchasing channels (direct mail orders, sales through telephone, salespersons, and TV stores), we have to mention that online store is the most popular channel (because of less costly communication). Communication channel could be used by online sellers to inform consumers about high level of security and privacy. The results of external communication could be measured by the number of people entering the store or the number of unique visits to the online store.

Talking about internal communication, the lack of physical contact and assistance in shopping online is one factor that influences the choice of traditional shopping. The need to touch, feel or try products is not possible in online store. On the other hand, personal-care products like perfume and products that require personal knowledge or experience like computers and cars are less likely to be considered while shopping online (Elliot \& Fowell, 2000). Thus in personal interaction with a sales person is required for the products under consideration, consumer's intention to shop on the online store is low. Interaction with sales person is very important for the first product choice, but for repeated purchases it is not very actual. Talking about backward communication in the retail sector, very common practice is evident for retailers to track consumers' basket via loyalty cards. Retailers use this data for drawing personalized perspectives (promotions, discount offers, etc.).

For the comparison of online and retail stores the development of the decision making tool will be delivered. Such tool will incorporate retail mix criteria.

\section{Online stores - new customer choice}

The absolute majority of the EU citizens agree that, in general, retailers/providers respect their rights as a consumer. The level of agreement is the highest in Luxembourg, Ireland, the UK, and Austria (from 77\% to 74\%). However, in Greece, Cyprus, in both Bulgaria and the Czech Republic only $37 \%$ or $41 \%$ of respondents think that retailers/providers respect their rights as a consumer (Eurobarometer, 2012).

The latest available statistical data about online stores via mystery shopping survey is collected by Meier-Pesti and Trubenbach (2009) in the study 'Mystery shopping evaluation of cross-border e-commerce in EU'. This statistical data covers international online sellers, located in the 27 European Union countries (according to the suffix or the registration of the company (in case the suffix is '.com', '.org', '.net', etc.)). The mentioned survey gives a very broad coverage of ecommerce in the European Union, covering 4.000 different online retailers in various product groups. In total, based on the mentioned survey, were tested 10.964 cross-border offers. 52\% of online sellers were represented by one offer, 17\% of stores - by two offers (from different product groups), other online stores (around 400 of them in total) - by three offers. The study shows the following situation in European Union: $34 \%$ of cross-border offers (in percentage of all offers) are not clear, if VAT is included in the initial price or not $\& 85 \%$ of cross-border offers have no final price given; terms and conditions are available for $87 \%$ of offers; information on the right of withdrawal is available for $84 \%$ of offers \& information on refunding is given for $64 \%$ of crossborder offers. Neither, regulation requires, such is inconvenient for the customer.

Overall, confidence in buying online domestically ranges from $80 \%$ in Denmark to $37 \%$ in both Cyprus and Malta; across borders, it ranges from $66 \%$ in Ireland to $25 \%$ in Hungary (Eurobarometer, 2012).

EU consumers are willing to purchase via the Internet both domestically and cross-border if they have Internet access at home. Across the EU, there is the difference in the level of online shopping recorded for all consumers (53\%) and for those with home Internet access (62\%). At 
national level, the widest differences are in the Hungary (49\% vs. 37\%), Germany (74\% vs. 63\%) and the United Kingdom (79\% vs. 68\%), where are considerably more consumers with home Internet access purchase online than all respondents (Eurobarometer, 2012).

In the online shopping context, consumers evaluate their Internet shopping experience from payment, risks involved, privacy, and security (Burke, 2002; Parasuraman \& Zinkhan, 2002; Mathwick, Malhotra \& Rigdon, 2001). The lack of trust is one of the most frequently cited reasons for customers not to shop on the Internet (Lee \& Turban, 2001). Rotter (1971) researched novel situations and found that people show trust. The most salient source of trust in a retail setting is the sales person, where consumer trust is dependent on the sales person's expertise, likeability, and similarity to the customer (Doney \& Cannon, 1997). Consumers cannot physically check the quality of a product or monitor the safety while shopping online. Trust has an important moderating shopping and intention to shop online (Lee \& Turban, 2001).

Nevertheless, online shopping fulfils several consumer demands more effectively and efficiently than retail shopping (Grewal, Iyer \& Levy, 2002; Chen \& Leteney, 2000; Haubl \& Trifts, 2000):

1) Online store consumers can browse the entire product-assortment with minimal effort and time;

2) Consumers can efficiently obtain critical knowledge about products, brands, and increase the competency in making decision while shopping;

3) Consumers can easily compare products features, availability, and prices more efficiently than with brick-and-mortar shopping. It is stated in the Commission of the European Communities (2009) survey that price difference is very important criteria for consumer choice between analysed stores.

4) Online store provides the level of anonymity for shopping sensitive products;

5) Online shopping offers the high level of convenience.

The main aspects, why consumers are satisfied with the online shopping, are the possibility to compare prices, the wider range of offers, the affordability of products, and the choice of alternative online stores. However, they have the biggest worries about the trustworthiness of online stores and the possibility to return commodities (Commission of the European Communities, 2009). The observed period of right on withdrawal in online stores lasts 13 days when the legal period of right on withdrawal is equal from 7 to 14 days (depends on the country of online store).

The survey of VeriSign (2009) shows that many purchasers request online sellers to use additional security technologies. Many customers are familiar with www.visa.com or VeriSign security technologies (which, for example, are used by banks in Lithuania). Following the guidelines of other studies, the authors recommend for consumers to buy form stores, which are using SSL certificates. Purchasers must feel unhesitatingly comfortable with the security measures (which businesses put in place to ensure security and confidentiality, and, in addition, must feel confident that these security measures are effective) (Lohse, Bellman \& Johnson, 2001). A high level of security and privacy in the online shopping experience has a positive effect on consumer trust and demand.

\section{Multiple criteria evaluation methods used for consumer choice analysis}

Multiple attribute decision-making problems are encountered under various situations where the number of alternatives and actions need to be chosen based on the set of attributes. When the separate set of alternatives described by some attributes is considered, three different types of analyses can be performed:

- Ensure that the decision-makers follow a 'rational' behaviour - utility theory, value functions, and distance to the ideal point;

- Give some advice based on reasonable (not indisputable) rules;

- Find the preferred solution for the partial decision hypothesis (Zavadskas, Kaklauskas, Turskis \& Tamošaitienè, 2009).

Multiple criteria evaluation methods are used to figure which alternative has received the 
highest score. Numerous methods have been developed for the multiple attribute analysis. Multiple attribute analysis is a useful tool in many economic, managerial, and other problems. Wide known methods used for multiple attribute decision making are TOPSIS, SWA, VIKOR, ELECTRE, COPRAS, etc.

The main steps for multiple attribute decision-making are these:

- establishing system for evaluation attributes;

- involving alternatives (generating alternatives);

- evaluating alternatives in terms of attributes (the values of the attributes);

- applying a normative multiple attributes analysis method;

- accepting one alternative with highest score (preferred);

- if the final solution is not accepted, new information has to be gathered, and the next iteration of multiple attributes optimization has to be made (based on Zavadskas et al., 2009).

Multiple criteria evaluation methods can be divided into two groups: etc).

1. Common (SR (sum of ranks), GM (geometrical mean), SAW (Simple Additive Weighting),

SR and GM do not take into consideration the criteria weights.

SAW is widely used in practice. It is similar to COPRAS, but SAW may use 'classical' normalization.

2. Complex (TOPSIS, ELECTRA, PROMETHEE, VIKOR, COPRAS, COPRAS-M, etc.).

One multiple criteria evaluation method is COmplex PRoportional ASsessment of alternatives (COPRAS) method. It assumes the direct and proportional dependence of significance and utility degree of the investigated versions on the system of criteria adequately describing the alternatives, values, and the weights of each criterion (Zavadskas, Simanauskas \& Kaklauskas, 1999).

In COPRAS-G (COmplex PRoportional ASsessment of alternatives with Grey relations) model, the parameters of alternatives are determined by the grey relational grade and expressed in intervals.

The accuracy of performance measures in COPRAS method is usually assumed to be precise. Sometimes, simplified version (COPRAS-M) of COPRAS method is used for multiple criteria evaluation.

TOPSIS and VIKOR are more complicated approaches sensitive to the variation of the initial data and the complex proportional evaluation; they differ in the criteria used and normalization technique of the initial data. TOPSIS (Technique for Order Preference by Similarity to Ideal Solution) - method used to analyse proximity to the ideal point (the alternative having the shortest distance to the ideal variant and the longest distance to the worst variant is chosen). TOPSIS is using non-standard, so-called vector normalization. VIKOR also uses the specific type of normalisation.

ELECTRE and PROMETHEE are outranking methods. Outranking defines a partial rank to the set of alternatives. It involves integer programming techniques to solve the optimization problem.

Fuzzy TOPSIS, fuzzy COPRAS, COPRAS-G or game theory methods, can be applied in the cases of uncertainty.

Commonly are used SAW, COPRAS, and TOPSIS: the first two have many common features, although the number of advantages and differences. SAW is the oldest representative of the most famous method used in practice. It accurately reflects the idea of quantitative multiple criteria methods - the indicator values and their weights are connected into a single value. Alternatives should be placed (ranked by method calculated the criterion values) in descending order. SAW method can be applied if all criteria, which have maximizing criteria values (when the largest value is the best). This is a SAW method limitation and discomfort (as minimising criteria values have to be transformed to maximising ones). COPRAS method is superior to the SAW method. COPRAS method involves both maximising and minimising criteria values. Under classic normalisation, the results of COPRAS method coincide with the results of SAW method. COPRAS 
allows to predict the influence of minimizing criteria values on the final result, to check the calculations and to take into account possible instability of estimates yielded by the method due to the specific character of the actual data (Podvezko, 2011). Podvezko (2011) paper describes the main features of multiple criteria evaluation methods SAW and COPRAS and their common and diverse characteristics, as well as defines and demonstrates the properties of the method COPRAS, which are of great theoretical and practical value. There is a possible to use both (SAW and COPRAS) for the evaluation of hierarchically structured composite factors (for more information see Podvezko (2011)).

Based on Podvezko (2011) research results, it is sufficient to use multiple criteria assessment techniques COPRAS in the study bellow.

\section{Results}

For a comparison of retail and online stores, multiple criteria evaluation method COPRAS and the set of six criteria is used. So, according to the retail mix the set consists of the following criteria:

a) Customer service;

b) Location (associated with travel and travel time costs);

c) Final price;

d) Store design and display;

e) Merchandise assortment;

f) Communication.

Each decision-maker has its own preferences. Each alternative (purchasing in retail and online store) in the quantitative evaluation is described by six criteria. Quantitative evaluation of such aspects allows defining their impact on the final decision. Some of them differed in optimization direction (Turskis, Zavadskas \& Peldschus, 2009). Maximising and minimising criteria are with different directions.

Bellow (see Table 2), the direction of criterion, which is maximizing or minimizing (i.e. max or min in column 2) is defined. For maximizing criteria, the largest value is the best, while for others (minimizing criteria) the smallest value is the best (Podvezko, 2011).

Table 2. The direction of criteria

\begin{tabular}{|l|c|}
\hline \multicolumn{1}{|c|}{ Criterion } & The direction of criterion \\
\hline a) Customer service & Max \\
\hline b) Location (associated with travel and travel time costs) & Min \\
\hline c) Final price & Min \\
\hline d) Store design and display & Max \\
\hline e) Merchandise assortment & Max \\
\hline f) Communication & Max \\
\hline
\end{tabular}

Source: created by the authors

During the application of COPRAS method direct and proportional dependencies are assumed; the alternatives, values, and weights of criteria are adequately described (Turskis, Zavadskas \& Peldschus, 2009). Among Lithuania scientists COPRAS method is used widely, for example, by Andriuškevičius (2005); Antuchevičienè, Zavadskas and Zakarevičius (2010); Bivainis and Drejeris (2009); Ginevičius and Podvezko, (2009); Ginevičius and Podvezko (2008); Ginevičius and Podvezko (2007); Kaklauskas, Gulbinas, Krutinis, Naimavičienė and Šatkauskas (2007); Kildienè, Kaklauskas and Zavadskas (2011); Malinauskas and Kalibatas (2005), and others.

The application of multiple criteria evaluation methods depends on the calculation of criteria weights. Usually for the estimation of weights experts are used. In case studies, the minimum of seven experts has to be used. For the checking consistency of experts' judgments, the coefficient of concordance is calculated (for more details see Appendix 1).

Based on COPRAS method, the multiple criteria problem is represented by a matrix. In our case, the matrix contains 6th criteria (rows) and X alternatives (columns) (see Appendix 2). 
In order to avoid the difficulties caused by different dimensions of all six criteria, the normalization has to be used. Before normalisation, the weights of criteria have to be placed into the decision table. After this, the matrix is normalized according formula (1). The sum of normalized values is equal as always to one (Turskis et al., 2009).

$$
D_{i j}=\frac{d_{i j} \cdot q_{i}}{\sum_{j=1}^{n} d_{i j}}, i=\overline{1,6} ; j=\overline{1, n}, \quad \sum_{i=1}^{6} \sum_{j=1}^{n} D_{i j}=1
$$

here: $D_{i j}$ is normalised value, $d_{i j}$ is the value of the criterion, $i$ - criterion value at $j$ store, $n$ - number of stores (alternatives) involved into comparison.

The following calculation of store $j$ describing minimizes and maximizes the normalized indicator is used.

In any case, the alternative of store and the sum is always equal to the maximizing $S_{+}$and minimizes $S$. criteria weight amounts:

$$
S_{+j}=\sum_{i=1}^{6} D_{+i j}, . j=\overline{1, n} \quad S_{-j}=\sum_{i=1}^{6} D_{-i j}, . j=\overline{1, n} \quad S_{+}=\sum_{j=1}^{n} S_{+j}=\sum_{i=1}^{6} \sum_{j=1}^{n} D_{+i j}, \quad S_{-}=1-S_{+}
$$

The alternatives are determined on the basis of describing them and taking into account the lowest with minimizing the value. The relative importance of alternatives is determined by the following formula:

$$
Q_{j}=S_{+j}+\frac{S_{-\min } \cdot \sum_{j=1}^{n} S_{-j}}{S_{-j} \cdot \sum_{j=1}^{n} \frac{S_{-\min }}{S_{-j}}}, j=\overline{1, n}
$$

In the final stage priority sequence is set. The greater the number $Q_{j}$, the higher priority is. According priority sequence $Q_{1}>Q_{2}>Q_{3}$ consumer should choose the store appeared in the first place.

Formulated decision making tool could be used for the ranking online and retail stores in proper priority sequence. It could be used for consumer purchasing decision. In addition, the proposed tool could be useful for authors, which analyse online and traditional shopping. Also, the developed profile further on has to be applied to case study looking up for practical evidence. There are different directions of its practical application: when it is used by group or individual decision makers.

In this study, the six linguistic term set with associated semantic is considered (see Appendix 3).

If stores are ranked by group of people (for example, belonging to the same household or to the group of friends), when decision matrix is more complex (see Appendix 4).

For the integration geometric mean, arithmetic mean or expert evaluation (when the weight per decision maker is given) could be used.

For the convenience of the evaluators, it is recommended to present calculation results in the form of a normalized value matrix, as is given in Appendix 5.

Now using Eq. 1-3 we get the final result - priority sequence (rank for each alternative). For example, alternative A1 gets rank 3, A2 - 1, A $3-2, \ldots$.

\section{Discussion}

The theoretical analysis of consumer choice models shows that for the purposes of modelling consumer choice between online and retail stores, the new decision making tool has to be formulated. The Behavioural perspective model - the decision making tool associated with consumer choice - is used to interpret the wide range of consumer behaviour cases: everyday purchasing, 'green' consumer behaviour, and compulsive behaviours. Also, the Model, as it involves situational factors, has been used to investigate different marketing phenomena, consumer 
brand choice. Channel choice model analyses online and offline sales and their cannibalization, but still more work is needed to understand the effect of competition between sites. Multiple attribute choice models (particularly multinomial logit models) focus on marketing issues. A normative methodology is used for modelling consumer response to innovation. With Bucklin and Lattin (1991) model consumer becomes 'looking forward'. The model is used to capture store switching effects; it involves loyalty to chain variables, category-wide feature variables (weighted average across brands), but the difficulty arises seeking to measure the effect of promotions on store choice.

A review of retail literature shows that for the comparison of online and retail stores, criteria essential for customers' decision, which also emphasize the differences of above mentioned stores, have to be involved; as there are more issues essential for consumers' decisions. In the paper, this theoretical knowledge is extended to the retail mix. New decision making tool is developed to capture the nature of online retail competition (e.g. to capture 'distance' through physical location when competition occurs between online and offline stores).

The analysis of various multiple criteria evaluation methods shows that COPRAS method can be used for the development of the decision making tool.

Finally, decision making tool, which incorporates retail mix criteria, is presented. Formulated tool is useful for the ranking online and retail stores in proper priority sequence and making choice between online and retail stores. Moreover, the proposed tool is not limited. It could be used for the comparison of stores located in any single environment (e.g. online or offline). The possible application of the decision making took showed that the linguistic and quantitative evaluation for such could be used. Also, it could be used by single or multiple decision makers. The developed tool could be useful for authors, which analyse online and traditional shopping.

The research has its limitations. So, future studies should expand this research to such directions:

- First, to the direction when the same retailers provide multiple purchasing channels;

- Second, to the direction of products selected from different categories into the basket;

- Third, to the direction of consumers' demographic characteristics;

- Fourth, the practical case assessment of proposed decision making tool is also suggested.

\section{References}

Alshurideh, M. T. (2014). A Qualitative Analysis of Customer Repeat Purchase Behaviour in the UK Mobile Phone Market. Journal of Management Research, 6 (1), 109-125. http://dx.doi.org/10.5296/jmr.v6i1.4659

Andriuškevičius, A. (2005). Evaluation of contractors by using COPRAS - the multiple criteria method. Technological and Economic Development of Economy, 3(11), 158-169.

Ansari, A. \& Mela, C.F. (2003). E-customization. Journal of Marketing Research, 4, 131-145. http://dx.doi.org/10.1509/jmkr.40.2.131.19224

Antuchevičienė, J., Zavadskas, E. K. \& Zakarevičius, A. (2010). Multiple criteria construction management decisions considering relations between criteria. Technological and Economic Development of Economy, 16(1), 109-125. http://dx.doi.org/10.3846/tede.2010.07

Avery, R.J. (1996). Determinants of search for non-durable goods: an empirical assessment of the economics of information theory. The Journal of Consumer Affairs, 30(2), 390-406. http://dx.doi.org/10.1111/j.1745-6606.1996.tb00064.x

Biyalogorsky, E. \& Naik, P. (2003). Clicks and Mortar: The Effect of On-line Activities on Off-line Sales. Marketing Letters, 14(1), 21-32. http://dx.doi.org/10.1023/A:1022854017292

Bivainis, J. \& Drejeris, R. (2009). Naujų paslaugų technologijos tinkamumo daugiakriterinis vertinimas. Business: theory and practice, 2(10), 93-106.

Bucklin, R. \& Lattin, J.M. (1991). A two-state model of purchase incidence and brand choice. Marketing Science, 10, 24-39. http://dx.doi.org/10.1287/mksc.10.1.24

Burinskiene, A. \& Burinskas, A. (2012). Consumer demand: e-commerce or traditional technologies. Economics \& management, 17(3), 963-970. http://dx.doi.org/10.5755/j01.em.17.3.2121 
Burke, R. R. (2002). Technology and the customer interface: what consumers want in the physical and virtual store. Journal of the Academy of Marketing Science, 30(4), 411-432. http://dx.doi.org/10.1177/009207002236914

Chen, S. \& Leteney, F. (2000). Get real! Managing the next stage of internet retail. European Management Journal, 18(5), 519-528. http://dx.doi.org/10.1016/S0263-2373(00)00041-4

Commission of the European Communities (2009). Report on cross-border e-commerce in the EU. Brussels, 74 p. Retrieved from http://ec.europa.eu/purchasers/strategy/docs/com_staff_wp2009_en.pdf.

DiClemente, D. F., Hantula, D. A. (2003). Applied behavioral economics and consumer choice. Journal of Economic Psychology, 24, 589-602. http://dx.doi.org/10.1016/S0167-4870(03)00003-5

Doney, P. M. \& Cannon, J. P. (1997). An examination of the nature of trust in buyer-seller relationships. Journal of Marketing, 61(2), 35-51. http://dx.doi.org/10.2307/1251829

Elliot, S. \& Fowell, S. (2000). Expectations versus reality: a snapshot of consumer experiences with Internet retailing. International Journal of Information Management, 20(5), 323-336. http://dx.doi.org/10.1016/S0268-4012(00)00026-8

Epp, A.M. \& Price, L.L. (2008). Family identity: a framework of identity interplay in consumption practices. Journal of Consumer Research, 1(35), 50-70. http://dx.doi.org/10.1086/529535

Eurobarometer (2008). Consumer protection in the internal market. Retrieved from http://ec.europa.eu/consumers/topics/eurobarometer_09-2006_en.pdf.

Eurobarometer (2012). Consumer attitudes towards cross-border trade and consumer protection. Retrieved from http://ec.europa.eu/public_opinion/flash/fl_358_en.pdf.

Foxall, G. (2009). Interpreting Consumer Choice - The Behavioural Perspective Model. Taylor \& Francis, $186 \mathrm{p}$.

Ginevičius, R. \& Podvezko, V. (2009). Evaluating the changes in economic and social development of Lithuanian counties by multiple criteria methods. Technological and Economic Development of Economy, 15(3), 418-436. http://dx.doi.org/10.3846/1392-8619.2009.15.418-436

Ginevičius, R. \& Podvezko, V. (2008). Multicriteria graphical-analytical evaluation of the financial state of construction enterprises. Technological and Economic Development of Economy, 14(4), 452-461. http://dx.doi.org/10.3846/1392-8619.2008.14.452-461

Ginevičius, R. \& Podvezko, V. (2007). Complex assessment of sustainable development of state regions with emphasis on ecological and dwelling conditions. Ecology, 53, 41-48.

Gluhovsky, I. (2009). Customer behavior model for quality-of-service environments with many service levels. Journal of Electronic Commerce Research, 10(1), 29-41.

Grewal, D., Iyer, G. R. \& Levy, M. (2002). Internet retailing: enablers, limiters and market consequences. Journal of Business Research, 12, 35-42.

Haubl, G. \& Trifts, V. (2000). Consumer decision making in online shopping environments: the effects of interactive decision aids. Marketing Science, 19(1), 4-21. http://dx.doi.org/10.1287/mksc.19.1.4.15178

Hauser, J. R. \& Urban, G. L. (2011). A normative methodology for modelling consumer response to innovation. Massachusetts Institute of Technology. Operations Research Center, $67 \mathrm{p}$.

Kaklauskas, A., Gulbinas, A., Krutinis, M., Naimavičienė, J. \& Šatkauskas, G. (2007). Mokymo procese naudojamų pasirenkamų modulių daugiavariantès analizės metodai. Technological and Economic Development of Economy, 3(13), 253-258.

Kildiene, S., Kaklauskas, A. \& Zavadskas, E. K. (2011). COPRAS based comparative analysis of the European country management capabilities within the construction sector in the time of crisis. Journal of Business Economics and Management, 12(2), 417-434. http://dx.doi.org/10.3846/16111699.2011.575190

Lee, M. K.O. \& Turban, E. (2001). A trust model for consumer internet shopping. International Journal of Electronic Commerce, 6(1), 75-91.

Lee, M. K., Kuo, C. \& Russell, M. G. (1999). The impact of perceived channel utilities, shopping orientations, and demographics on the consumer's online buying behaviour. Journal of ComputerMediated Communication, 5(2), 25-37.

Lohse, G. L., Bellman, S. \& Johnson, E. J. (2000). Consumer buying behaviour on the internet: findings from panel data. Journal of Interactive Marketing, 14(1), 15-29. http://dx.doi.org/10.1002/(SICI)15206653(200024)14:1<15::AID-DIR2>3.0.CO;2-C 
Louiviere, J., Hensher, D. \& Swait, J. (2000). Stated choice methods: analysis and application. Cambridge: Cambridge University Press, 399 p. http://dx.doi.org/10.1017/CBO9780511753831

Malinauskas, P. \& Kalibatas, D. (2005). Racionalių statybos technologiniu procesu parinkimas taikant COPRAS metodą. Technological and Economic Development of Economy, 11(3), 197-203.

Mathwick, C., Malhotra, N. K. \& Rigdon, E. (2002). The effect of dynamic retail experiences on experiential perception of value: an Internet and catalogue comparisons. Journal of Retailing, 78(1), 51-60. http://dx.doi.org/10.1016/S0022-4359(01)00066-5

Meier-Pesti, K. \& Trubenbach, C. (2009). Mystery shopping evolution of cross-border e-commerce in the EU. YouGovPsychonomics, 105 p.

Parasuraman, A. \& Zinkhan, G. M. (2002). Marketing to and serving customers through the Internet: an overview and research agenda. Journal of the Academy of Marketing Science, 30(4), 286-295. http://dx.doi.org/10.1177/009207002236906

Podvezko, V. (2011). The Comparative Analysis of MCDA Methods SAW and COPRAS. Engineering Economics, 22(2), 134-146. http://dx.doi.org/10.5755/j01.ee.22.2.310

Podvezko, V. (2005). Agreement of expert estimates. Technological and Economic Development of Economy, 2(11), 101-107.

Rotter, J. B. (1971). Generalized expectancies for interpersonal trust. American Psychologist, 26(5), 443-452. http://dx.doi.org/10.1037/h0031464

Snieška V., Virvilaitė, R., Kvainauskaitè, V., Neverauskas, B., Gatautis, R. \& Dovalienė, A. (2007). IT Market and E-Commerce in Transition Economy: Network Externalities. In Heijman, W. et al. (Ed.), Regional externalities (pp. 149-172). London, UK: Springer. http://dx.doi.org/10.1007/978-3-54035484-0_8

Statistics department of Lithuania (2009). On-line database. Retrieved from http://db1.stat.gov.lt/statbank/.

Thomas, J. S. \& Sullivan, U. Y. (2005). Managing Marketing Communications with Multichannel Customers. Journal of Marketing, 69 (4), 239-51. http://dx.doi.org/10.1509/jmkg.2005.69.4.239

Turskis, Z., Zavadskas, E. K. \& Peldschus, F. (2009). Multi-criteria optimization system for decision making in construction design and management. Engineering Economics, 1(61), 7-17.

VeriSign (2009). E-commerce, trust, and SSL. Retrieved from http://www.verisign.com/ssl/ssl-informationcenter/ecommerce-trust-ssl/index.html.

Wierenga, B. (2008). Handbook of Marketing Decision Models. Springer, 625 p. http://dx.doi.org/10.1007/978-0-387-78213-3

Wolfinbarger, M. \& Gilly, M. C. (2001). Shopping online for freedom, control, and fun. California Management Review, 43(2), 34-55. http://dx.doi.org/10.2307/41166074

Zhang, J. \& Krishnamurthi, L. (2004). Customizing promotions in online stores. Marketing Science, 24(4), 561-578. http://dx.doi.org/10.1287/mksc.1040.0055

Zavadskas, E. K., Kaklauskas, A., Turskis, Z. \& Tamošaitienė, J. (2009). Multi-attribute decision-making model by applying grey numbers. Informatica, 20(2), 305-320.

Zavadskas, E. K., Simanauskas, L. \& Kaklauskas, A. (1999). Sprendimu paramos sistemos statyboje. Vilnius: Technika.

Zeileis, A. \& Croissant, Y. (2010). Extended Model Formulas in R: Multiple Parts and Multiple Responses. Journal of Statistical Software, 34(1), 1-13.

\section{Appendixes}

Appendix 1. Calculation of concordance coefficient

The sum $c$ of scores $c_{i j}$, presented by experts is calculated:

$$
c=\sum_{e=1}^{r} c_{i e}(i=1, \ldots, n)
$$

here $n$ is the number of criteria; $r$ - the number of experts (which is equal to 7), $i$ - the particular number of criterion, $e-$ the particular expert. 


$$
q_{i}=\frac{c_{i}}{c}, \quad \sum_{i=1}^{5} q_{i}=1
$$

here $q$ is significance of criterion (weight), $c_{i}-$ all scores for criterion $i$.

The coefficient of concordance $W$ is calculated according such formula:

$$
W=\frac{N}{N_{\max }} \text {, when } N=\sum_{i=1}^{n}\left(c_{i}-\bar{c}\right)^{2}, \text { where } \bar{c}=\frac{1}{2} r(n+1)=\frac{1}{2} \cdot 7 \cdot(6+1)=24.5
$$

here $\bar{c}$ is overall average, $N$ - the sum of deviations, which shows difference from average squared, $N_{\max }-$ the sum of deviations in ideally agreed case, which is calculated:

$$
N_{\max }=\frac{r^{2} n\left(n^{2}-1\right)}{12}=\frac{49 \cdot 6 \cdot\left(6^{2}-1\right)}{12}=857.5
$$

The significance $x^{2}$ for the coefficient of concordance is calculated as follows:

$$
x^{2}=W r(n-1)=W \cdot 7 \cdot(6-1)=35 \cdot W
$$

Random number $x^{2}$ is distributed under $x^{2}$ with the degrees of freedom $\mathrm{v}$ (then $v=n-1$ ) of the chosen significance level $\alpha$ (in practice $\alpha$ is usually equal to the value of 0.05 or 0.01 ). The assessments of experts are aligned calculated $x^{2}$ value is greater than the $x_{k r}\left(x_{k r}\right.$ value is taken from the tables of distribution with $v=6-1=5$ the degrees of freedom and significance level $\alpha=0.05$ and is equal to 11.07).

The coefficient of concordance is equal to $W$ (if its significance equal to $x^{2}$ is greater than the critical

\begin{tabular}{|c|c|c|c|c|c|c|c|c|}
\hline \multicolumn{3}{|c|}{ Criteria } & \multicolumn{5}{|c|}{ Alternatives } & Sum of values \\
\hline \multirow{2}{*}{ Name } & \multirow[t]{2}{*}{ Direction } & \multirow{2}{*}{ Weight } & A1 & $\mathrm{A} 2$ & A3 & $\ldots$ & An & \\
\hline & & & \multicolumn{5}{|c|}{ Values for each criterion } & \\
\hline $\mathrm{C}_{1}$ & $\operatorname{Max}$ & $\mathrm{q}_{1}$ & $d_{11}$ & $\mathrm{~d}_{12}$ & $\mathrm{~d}_{13}$ & $\ldots$ & $\mathrm{d}_{1 \mathrm{n}}$ & \\
\hline $\mathrm{C}_{2}$ & Min & $\mathrm{q}_{2}$ & $\mathrm{~d}_{21}$ & $d_{22}$ & $d_{23}$ & $\ldots$ & $d_{2 n}$ & $S_{2}=\sum^{n} d_{2 j}$ \\
\hline $\mathrm{C}_{3}$ & Min & $\mathrm{q}_{3}$ & $d_{31}$ & $d_{32}$ & $d_{33}$ & $\ldots$ & $d_{3 n}$ & $S_{3}=\sum_{j=1}^{n} d_{3 j}$ \\
\hline $\mathrm{C}_{4}$ & $\operatorname{Max}$ & $\mathrm{q}_{4}$ & $d_{41}$ & $\mathrm{~d}_{42}$ & $\mathrm{~d}_{43}$ & ... & $\mathrm{d}_{4 \mathrm{n}}$ & $S_{4}=\sum_{j=1}^{n} d_{4 j}$ \\
\hline $\mathrm{C}_{5}$ & $\operatorname{Max}$ & $\mathrm{q}_{5}$ & $d_{51}$ & $d_{52}$ & $\mathrm{~d}_{53}$ & $\cdots$ & $d_{5 n}$ & \\
\hline $\mathrm{C}_{6}$ & $\operatorname{Max}$ & $\mathrm{q}_{6}$ & $\mathrm{~d}_{61}$ & $d_{62}$ & $d_{63}$ & $\cdots$ & $d_{6 n}$ & $S_{6}=\sum_{j=1}^{n} d_{6 j}$ \\
\hline
\end{tabular}
value - equal to 11.07) when experts' judgments are in good agreement. This shows if results obtained can be used (Podvezko, 2005).

\section{Appendix 2. Matrix}

Source: created by the authors

Appendix 3. Label set

\begin{tabular}{ccc}
\hline Label set & Linguistic term & Value \\
\hline$k_{1}$ & Nothing to say & 0 \\
\hline$k_{2}$ & Bad & 0.2 \\
\hline$k_{3}$ & Not satisfactory & 0.4 \\
\hline$k_{4}$ & Satisfactory & 0.6 \\
\hline$k_{5}$ & Good & 0.8 \\
\hline$k_{6}$ & Very good & 1.0 \\
\hline
\end{tabular}

Source: created by the authors 
Appendix 4. Rating the stores with respect to different decision makers

\begin{tabular}{|c|c|c|c|c|c|}
\hline \multirow{2}{*}{ Criteria } & \multirow{2}{*}{ Alternatives } & \multicolumn{4}{|c|}{ Decision makers } \\
\cline { 2 - 6 } & & $\mathrm{M}_{1}$ & $\mathrm{M}_{2}$ & $\ldots$ & $\mathrm{M}_{\mathrm{u}}$ \\
\hline \multirow{3}{*}{$\mathrm{C}_{1}$} & $\mathrm{~A} 1$ & $\mathrm{k}_{5}$ & $\mathrm{k}_{4}$ & $\ldots$ & $\mathrm{k}_{4}$ \\
\cline { 2 - 6 } & $\mathrm{A} 2$ & $\mathrm{k}_{3}$ & $\mathrm{k}_{5}$ & $\ldots$ & $\mathrm{k}_{2}$ \\
\cline { 2 - 6 } & $\mathrm{A} 3$ & $\mathrm{k}_{2}$ & $\mathrm{k}_{3}$ & $\ldots$ & $\mathrm{k}_{4}$ \\
\hline \multirow{3}{*}{$\mathrm{C}_{2}$} & $\mathrm{~A} 1$ & $\mathrm{k}_{4}$ & $\mathrm{k}_{2}$ & $\ldots$ & $\mathrm{k}_{5}$ \\
\cline { 2 - 6 } & $\mathrm{A} 2$ & $\mathrm{k}_{2}$ & $\mathrm{k}_{6}$ & $\ldots$ & $\mathrm{k}_{1}$ \\
\cline { 2 - 6 } & $\mathrm{A} 3$ & $\mathrm{k}_{3}$ & $\mathrm{k}_{6}$ & $\ldots$ & $\mathrm{k}_{2}$ \\
\hline \multirow{3}{*}{$\mathrm{C}_{3}$} & $\mathrm{~A} 1$ & $\mathrm{k}_{2}$ & $\mathrm{k}_{5}$ & $\ldots$ & $\mathrm{k}_{3}$ \\
\cline { 2 - 6 } & $\mathrm{A} 2$ & $\mathrm{k}_{6}$ & $\mathrm{k}_{1}$ & $\ldots$ & $\mathrm{k}_{1}$ \\
\cline { 2 - 6 } & $\mathrm{A} 3$ & $\mathrm{k}_{5}$ & $\mathrm{k}_{3}$ & $\ldots$ & $\mathrm{k}_{3}$ \\
\hline \multirow{3}{*}{$\mathrm{C}_{4}$} & $\mathrm{~A} 1$ & $\mathrm{k}_{3}$ & $\mathrm{k}_{1}$ & $\ldots$ & $\mathrm{k}_{4}$ \\
\cline { 2 - 6 } & $\mathrm{A} 2$ & $\mathrm{k}_{5}$ & $\mathrm{k}_{6}$ & $\ldots$ & $\mathrm{k}_{5}$ \\
\cline { 2 - 6 } & $\mathrm{A} 3$ & $\mathrm{k}_{4}$ & $\mathrm{k}_{5}$ & $\ldots$ & $\mathrm{k}_{2}$ \\
\hline \multirow{3}{*}{$\mathrm{C}_{5}$} & $\mathrm{~A} 1$ & $\mathrm{k}_{2}$ & $\mathrm{k}_{3}$ & $\ldots$ & $\mathrm{k}_{6}$ \\
\cline { 2 - 6 } & $\mathrm{A} 2$ & $\mathrm{k}_{5}$ & $\mathrm{k}_{1}$ & $\ldots$ & $\mathrm{k}_{3}$ \\
\cline { 2 - 6 } & $\mathrm{A} 3$ & $\mathrm{k}_{5}$ & $\mathrm{k}_{2}$ & $\ldots$ & $\mathrm{k}_{5}$ \\
\hline \multirow{3}{*}{$\mathrm{C}_{6}$} & $\mathrm{~A} 1$ & $\mathrm{k}_{1}$ & $\mathrm{k}_{1}$ & $\ldots$ & $\mathrm{k}_{6}$ \\
\cline { 2 - 6 } & $\mathrm{A} 2$ & $\mathrm{k}_{5}$ & $\mathrm{k}_{3}$ & $\ldots$ & $\mathrm{k}_{1}$ \\
\cline { 2 - 6 } & $\mathrm{A} 3$ & $\mathrm{k}_{6}$ & $\mathrm{k}_{5}$ & $\ldots$ & $\mathrm{k}_{4}$ \\
\hline
\end{tabular}

Source: created by the authors

Appendix 5. Normalised value matrix

\begin{tabular}{|c|c|c|c|c|c|c|c|c|c|c|}
\hline Alternatives & \multicolumn{6}{|c|}{ Criteria } & \multirow{3}{*}{$\begin{array}{c}\text { Sum of } \\
\text { normalized } \\
\text { maximizing } \\
\text { indicators }\end{array}$} & \multirow{3}{*}{$\begin{array}{l}\text { Sum of } \\
\text { normalized } \\
\text { minimizing } \\
\text { indicators }\end{array}$} & \multirow{3}{*}{$\begin{array}{c}\text { Relative } \\
\text { importance } \\
\text { of } \\
\text { comparable } \\
\text { variants }\end{array}$} & \multirow{3}{*}{$\begin{array}{l}\text { Priority } \\
\text { sequence }\end{array}$} \\
\hline Name & $\mathrm{C}_{1}$ & $\mathrm{C}_{2}$ & $\mathrm{C}_{3}$ & $\mathrm{C}_{4}$ & $\mathrm{C}_{5}$ & $\mathrm{C}_{6}$ & & & & \\
\hline & \multicolumn{6}{|c|}{ Normalised values } & & & & \\
\hline A1 & $\mathrm{D}_{11}$ & $\mathrm{D}_{21}$ & $\mathrm{D}_{31}$ & $\mathrm{D}_{41}$ & $\mathrm{D}_{51}$ & $\mathrm{D}_{61}$ & $\mathrm{~S}_{+1}$ & $\mathrm{~S}_{-1}$ & $\mathrm{Q}_{1}$ & \\
\hline A2 & $\mathrm{D}_{12}$ & $\mathrm{D}_{22}$ & $\mathrm{D}_{32}$ & $\mathrm{D}_{42}$ & $\mathrm{D}_{52}$ & $\mathrm{D}_{62}$ & $\mathrm{~S}_{+2}$ & $\mathrm{~S}_{-2}$ & $\mathrm{Q}_{2}$ & \\
\hline A3 & $\mathrm{D}_{13}$ & $\mathrm{D}_{23}$ & $\mathrm{D}_{33}$ & $\mathrm{D}_{43}$ & $\mathrm{D}_{53}$ & $\mathrm{D}_{63}$ & $\mathrm{~S}_{+3}$ & $\mathrm{~S}_{-3}$ & $\mathrm{Q}_{3}$ & \\
\hline$\ldots$ & $\ldots$ & $\ldots$ & $\ldots$ & $\ldots$ & $\ldots$ & $\ldots$ & $\ldots$ & $\ldots$ & $\cdots$ & \\
\hline An & $\mathrm{D}_{1 \mathrm{n}}$ & $\mathrm{D}_{2 \mathrm{n}}$ & $D_{3 n}$ & $\mathrm{D}_{4 \mathrm{n}}$ & $\mathrm{D}_{5 \mathrm{n}}$ & $\mathrm{D}_{6 \mathrm{n}}$ & $\mathrm{S}_{+\mathrm{n}}$ & $\mathrm{S}_{-\mathrm{n}}$ & $\mathrm{Q}_{\mathrm{n}}$ & \\
\hline Sum & $\mathrm{D}_{1 \mathrm{j}}$ & $\mathrm{D}_{2 \mathrm{j}}$ & $D_{3 j}$ & $\mathrm{D}_{4 \mathrm{j}}$ & $\mathrm{D}_{5 \mathrm{j}}$ & $\mathrm{D}_{6 \mathrm{j}}$ & \multicolumn{2}{|c|}{$\sum_{i=1}^{6} \sum_{j=1}^{n} D_{i j}=S_{+}+S_{-}=1$} & & \\
\hline
\end{tabular}

Source: created by the authors 